\title{
Bidirectional Cultural Infiltration in College English Writing Teaching
}

\author{
Wenlan Zhao \\ College of Foreign Languages, Bohai University, Jinzhou, 121013, China \\ 724222790@qq.com
}

Keywords: English writing teaching; bidirectional cultural infiltration; significance; principles; strategies

\begin{abstract}
It is an effective way to improve English writing teaching that making bidirectional cultural infiltration in English writing teaching to cultivate the students' bidirectional culture awareness and cross-cultural communication ability, which lets the contents that students write more in line with English thinking habits. This paper analyzes the significance of bidirectional cultural infiltration in English writing teaching, points out the principles of respect, moderation, stage and comparison that bidirectional cultural infiltration should follows, proposes the bidirectional culture penetrating strategy. Specific strategies include: comparative analysis of cultural differences, full use of the advantages of modern education technology, a full range of cultural infiltration, enrich classroom and extracurricular life, comprehensive use of various teaching methods and strengthen local culture elements input and so on. In the actual teaching, combining students' situation to use selectively these strategies to improve the teaching effect of English writing.
\end{abstract}

\section{Introduction}

Language is created by human beings, which is human's most important communication tool, and the main expression means for people to communicate, people use language to save and transfer the achievements of human civilization. Culture is the sum total of material wealth and spiritual wealth created by human beings, it is a kind of social phenomenon, which is also a historical phenomenon and the accumulation of social history, every generation inherits the original culture, at the same time, constantly abandon and update the original culture, which is contribute to the development of social culture. Different countries have different language and culture, language and culture are interdependent and interactive each other, language is an important carrier of culture, which is the most important cultural transmission tool; culture also has a restrictive effect on language, cultural differences may cause the inconvenience and misunderstanding in the language communication.

The fundamental purpose of English teaching is to cultivate students' ability to use English to communicate, which is the starting point and end result of English teaching, as well as the general idea of English teaching. American linguist Sapir in a book called Language points out: "Language has environment, it cannot exists without culture and inherits traditions and beliefs without society". Therefore, in order to successfully communicate with people of different culture, it is necessary to understand the particular social cultural background of the language. Language learners should not only learn the language form, but also learn the culture connotation, that is the language in culture and the culture in language. In order to improve the ability of language application, English teaching must pay attention to cultural infiltration, cannot simply carry on language teaching, but also attach great importance to the cross-cultural education to help students clear obstacles which are emerged in language communication.

English writing ability is one of the important aspects of five skills of students' English language (listening, speaking, reading, writing and translating), cultivating students with strong English writing ability is an important task of English course teaching. The present situation of college English writing teaching is not optimistic, students' satisfaction with English writing teaching is low, outstanding problems perform in that students' English basic skills are not solid, students' English language ability is poor, write according to the Chinese habit, writing teaching mode is obsolete and the lack of Chinese and western cultural knowledge and so on. Writing is still the weak link of 
English teaching at present, constantly sum up experience in teaching, make analysis of the errors students often make in English writing, in a timely manner to improve teaching methods, in order to improve the teaching quality of English writing courses, which is an important task of English writing teaching. Traditional writing teaching only pay attention to the correctness of the language, teachers take the teaching of language points as the key point, rarely give the real language environment, rarely at the cultural level make analysis of language differences, which makes a lot of students get a better mastery of the vocabulary and grammar knowledge, but always use Chinese thinking habits to make English expression, the result is that it is difficult to improve the writing level. Making cultural infiltration in the writing teaching to cultivate cross-cultural awareness, which lets the contents that students write out more in line with English thinking habits, so as to achieve the purpose of improving the ability of language applications.

\section{Significance on Bidirectional Cultural Infiltration}

Making bidirectional introduction of two kinds of Chinese and Western cultures in the teaching of English writing to realize the bidirectional infiltration of the culture of the "target language" and the "native language", and establish a new type of language teaching mode which cultivates students' bidirectional cultural accomplishments and cross-cultural communication abilities as the background, the "native language" culture and the "target language" culture as the content, combined cultural input and output. The specific meaning is as follows:

First, deepen the understanding of Chinese culture, improve the ability of cultural identification. If foreign language education too much emphasis on the western culture, ignoring the Chinese excellent culture, which inevitably leads to the loss of national self-confidence, so that makes western culture spread. Achieve two kinds of cultural infiltration, in-depth understanding of Chinese culture, compare two kinds of the culture of Chinese and foreign, set up the national self-confidence, enhance the sense of national pride.

Second, expand the extracurricular knowledge, increase the interest in learning English. Culture involves history and politics, human geography, local conditions and customs and social etiquette of human development, while learning languages, expanding the knowledge outside disciplines to integrate the boring language learning into the process of autonomous inquiry scientific and cultural knowledge, which lets students in the expanded field of vision, at the same time, increase the enthusiasm of learning English language.

Third, improve comprehensive quality, cultivate the ability of intercultural communication. Through cultural infiltration, effectively absorb the British and American excellent civilization, adjust own bad habits, enhance personal accomplishment. On the basis of the understanding of foreign cultures, adopting respect, tolerant and open attitude, loving and carrying forward the native excellent tradition, drawing on and assimilating outstanding excellent essence which promotes common prosperity and development of all kinds of cultures.

\section{Principles on Bidirectional Cultural Infiltration}

Bidirectional cultural infiltration in English writing teaching should follow principles:

First, respect principle. National culture is the inheritance and accumulation of generations and generations, which has a long history. Chinese culture and western culture both have respective national characteristics, only on the basis of mutual respect, it can be done that in peace mind to examine and absorb its essence.

Second, moderation principle. Cultural infiltration should grasp the scale, distinguish between primary and secondary. The contents belong to the mainstream culture are explained in detail, which makes students understand the sequence of events of cultural traditions and customs, encourage students to make a large number of extracurricular reading and practice. A brief introduction on non-mainstream culture is made to save time.

Third, phase principle. Cultural infiltration should be based on the students' language level and receptive ability, give full consideration on the cognitive ability and age characteristics, follow the 
main line that shallower to deeper, simple to complex and phenomenon to nature, expand and deepen step by step.

Forth, comparison principle. Compare the native culture with the western culture, at the same time find out the similarities and differences. Deepen the cognition of the target culture, understand the western thinking way and value orientation, deeply understanding different cultural behavior, so as to avoid to use own standards to ask or explain the behavior of other people.

\section{Strategies on Bidirectional Cultural Infiltration}

The cultural education in the foreign language teaching is a process advanced in regular order which takes cultural knowledge as the starting point, cultural consciousness as bridges, cultural understanding as purposes. Bidirectional cultural infiltration is an important task of English writing teaching, the specific strategies are as follows:

First, comparative analysis of cultural differences. Cultural differences refers to the differences produced due to different regions, peculiar cultural similarities and differences owned to people in different regions. Teachers carry on comparative analysis to Chinese culture and English national culture in the process of writing teaching, which lets students understand the commonness and individuality between cultures, deepens understanding of English national culture and Chinese culture, understand the cultural orientation of different countries and different ethnic groups, cultivate students' attitude of tolerance, openness and understanding, so as to improve the ability of intercultural communication. Chinese and western culture are mainly manifested in six aspects: the differences of integrity and individuality, the differences in talking, the differences of values and moral standards, the differences of social relations, the differences of social etiquette, the differences of social customs. That is western culture advocates personal honor, self-centeredness, innovation spirit and individual freedom; Chinese culture advocates modest and prudent, selfless dedication, the middle course and unity cooperation; westerners have stronger equality consciousness, the family structure is simple, the core family consists of parents and minor children; Chinese have stronger hierarchy sense, the family structure is more complex, many traditional happy families have four generations. Simply summing up these differences is not complicated, reflected on the way of thinking is the differences between the abstract and concrete, reflected on the life attitude can be understood as that westerners are more practical, Chinese much more emphasis on some spiritual feelings.

Second, give full play to the advantages of modern educational technology. Modern educational technology is a system of modern education means and methods which takes modern information technology as the means, applies modern education theory in education and teaching practice. As the representative of modern education technology, multimedia plays a unique role in the teaching process of English writing, embodied in the following three aspects: first, stimulate interest in writing. Interest is the best teacher, positive thinking activity is based on strong learning interest and rich emotion. Improve the teaching effect of English writing, the first is to stimulate students' interest, arouse the enthusiasm of students' writing. Multimedia makes traditional abstract and boring teaching contents become lively and interesting, and bring students into the atmosphere corresponding the teaching content, which makes students have an immersive feeling and stimulates students' interest in learning and the desire of seeking knowledge to maximize; second is to create writing environment. John Dewey points out that teaching should be based on students' experience or activities, learners should have a kind of "the real environment of experience". In the classroom creating rich and colorful and vivid writing scenes and atmosphere, making full use of combined characteristics of sound and image, dynamic and static, far and near, outside and inside, virtual and real of multimedia technology, highlighting image and dynamic sense, which causes student to have an immersive feeling; third is to promote writing thinking. Many students often make Chinese English errors in the process of writing, which is the result of thinking habits. Adopting electronic writing can automatically correct words and simple syntax errors, alleviate students' writing pressure, students will pay attention to the quality of information transmission and text structure organization, which promotes the development of students' writing thinking. 
Third, comprehensive cultural infiltration. It specifically includes three aspects: first is language construction culture, the culture associated with language structure, which refers to the cultural characteristics reflected by words, phrases, sentences and discourse structure, namely the differences of language structure caused by different cultural backgrounds. A nation's cultural psychology structure and world view are deeply embedded in the language structure. Cultural characteristics embodied in the language structure reflect the nation's psychological model and thinking mode. Combining the explanation and grammar of language structure culture analysis on the culture factors of bidirectional language structure from the perspective of cognitive linguistics; second is the semantic culture, the culture related to background knowledge, which refers to the contained cultural contents and reflected cultural psychology, national spirit and philosophic thinking of language semantic system. On the one hand, culture influences the formation and development of the semantic, on the other hand, the semantic reveals in turn the rich and colorful national culture. Not only to let students understand the common culture of two ethnics of English and Chinese, but also to understand the characteristic culture, which includes the living habits, customs, philosophy, thinking ways, values, literature and art, aesthetic taste, humanistic thought and religious belief and so on. At the same time, should also make students master the semantic cultural connotation behind words, master the use occasions, use object and emotional color of vocabulary; three is that pragmatic culture, which is the culture related to communication skills, refers to the cultural rules and cultural norms used by languages in the communication, determined by different national culture, especially the custom culture. From the perspective of foreign language teaching, this kind of cultural infiltration related to pragmatics can include the call, greetings and regards, thanks and gratitude, honorific and self-depreciatory expression, farewell, praise and humility, taboo and euphemism and so on.

Fourth, enrich the classroom and extracurricular life. Teaching is not only a means that students acquire knowledge and ability, but also associated with students' happy and healthy growth. English writing teaching should also be given life, closely linked with students' life, which forms a rich classroom and extracurricular life, in favor of students to understand the abstract cultural knowledge. First is to dig the teaching material contents, create real cultural life scene. While make writing teaching, provide the time and space of intercultural teaching, using appropriate ways to enable students to experience foreign culture in a relaxed and pleasant atmosphere, develop the habit of using English thought and appropriate communicative abilities in the specific context. Second is to expand the teaching material content, organize students to read extensively. In order to enrich all aspects of students' cultural knowledge, encourage students to read English books widely, open the window of students' thought, not only to pay attention to the plot and literature review, but also to pay more attention to the cultural details. Extensive reading also helps students to deeply understand western culture, which includes the values, morality, philosophy of life, lifestyle and so on. So that students can fully understand the culture of the target language, and open the thinking window. In order to achieve and penetrate, and also guide students to read Chinese classic literatures, have a profound understanding of traditional Chinese culture, which achieves mastery of Chinese culture and foreign culture.

Fifth, the integrated use of a variety of teaching methods. Under the guidance of modern teaching theory, the characteristics of all kinds of teaching methods are skillfully grasped, the teaching methods are selected reasonably and optimized combination. The common teaching methods used in English writing have the following three kinds: one is the result teaching method, which thinks writing is mainly related to language knowledge, focusing on the appropriate use of vocabulary, syntax and cohesive devices. Emphasis on students' language knowledge input, Integrating bidirectional culture into the process of the presentation and explain of excellent model essay lets students have sufficient prepare of language and culture knowledge, and through the explain of the chapter structure train students' English thinking abilities; second is the process teaching method, which thinks writing is a kind of group communication activities, not the writer's individual behavior, it divides the writing process into four stages such as preparation, writing, modifying and editing, Responsibility of teachers is to make writing become a kind of collaborative 
learning process, through the explain of cultural knowledge, arouse the enthusiasm of students' writing, and improve the writing interest; three is the genre teaching method, which carries out teaching activities surrounding the schema structure of the discourse, thinks the purpose of communication is the decisive factor of genre, the writing process is divided into three steps such as demonstration analysis, joint consultation and independent creation, emphasizes writing activities are conditioned by specific social situations, serve for the specific purpose, while explains the communicative purpose, explains culture. no matter which kind of teaching method is chose, it should be done that the heuristic teaching thought is taken as the guiding ideology, more attention should be pay on students' participation in the teaching process.

Sixth, strengthen the input of local culture elements. Cultural knowledge subject involved in the English teaching is the British and American culture, Chinese culture is often neglected, the Chinese culture aphasia emerges. Many students are familiar with the development of western culture, but they do not understand the essence of Chinese culture. "Let China go to the world, let the world know about China" has become a consensus, under the context of international cultural exchange, foreign language teaching must adapt to the trend of the times, establish the new teaching mode that foreign language teaching connected with world culture, combined with local culture. In the writing teaching, appropriately adding the local culture knowledge can not only increase the diversity and interest of English writing teaching, but also can increase students' awareness of Chinese culture, find the breakthrough point of the local culture infiltration in English teaching. Specific methods can have the following points: one is to change the English writing teaching outline, clear and definite the specific requirements of the local culture quality training; second is to pay attention to the construction of teaching materials, add the local culture contents in the teaching material; three is to reform the teaching methods, reflect the local culture connotation in the aspects of teaching language, teaching mode and teaching interaction; four is to moderately add investigation contents of local cultural knowledge in all levels of English exams to promote learning; five is to improve English teachers' native cultural knowledge accomplishment, and understand broad and profound Chinese culture; six is to cultivate students' native culture consciousness, set up the correct culture viewpoint, promote to use English to write Chinese excellent traditional culture. Strengthening the local culture input in the foreign language teaching is not to weaken the foreign language teaching, nor transfer center, but the deepening of the language teaching.

\section{Conclusion}

English language teaching and bidirectional cultural infiltration are two very important links in the process of teaching, they complement with each other. Bidirectional cultural infiltration help students understand British and American culture and spread Chinese culture, deepen the understanding and grasp of language itself. This puts forward higher requirements to teachers to continuously improve teaching methods and Chinese cultural knowledge accomplishment, often absorb British and American national society, culture, and life information, which make Chinese culture integrated with British and American culture, and put into writing teaching practice to cultivate students' cross-cultural awareness, improve the ability of mastering language and applying language, so as to realize the purpose of English teaching.

\section{Acknowledgement}

This work is supported by social science fund project of Liaoning province: Research on bidirectional cultural teaching in college English writing teaching (L15BYY008).

\section{References}

[1] H. Li, "Study on the strategies of College English classroom teaching in the direction of improving cultural soft power," Education Modernization, vol. 3, no. 8, pp. 262-264, 2016. 
[2] X. P. Wang, "Improve the English writing level in the cultural infiltration," Educational Practice and Research, vol. 36, no. 11, pp. 48-49, 2014.

[3] X. M. Chen, J. Liu, "English major students writing present situation investigation and strategy research," Overseas English, vol. 15, no. 23, pp. 124-125, 2014.

[4] H. R. Yan, "Local culture infiltration in colleges foreign language teaching," Journal of Jiamusi Vocational Institute, vol. 32, no. 1, pp. 135-136, 2015.

[5] Y. Zhang, "On culture teaching in college English teaching," English Square(Academic Research), vol. 2, no. 7, pp. 102-103, 2012.

[6] X. Y. Wu, "The significance of English culture and the strategy of cultural infiltration," Journal of Taiyuan Urban Vocational College, vol. 14, no. 10, pp. 203-205, 2012.

[7] S. Yin, "On the way and significance of Chinese cultural infiltration in college English teaching," Journal of Mudanjiang University, vol. 23, no. 1, pp. 154-155, 2014.

[8] Y. M. Yao, "On Cultural Infiltration and Foreign Language Teaching," Journal of Yan'an Vocational \& Technical Institute, vol. 23, no. 6, pp. 75-77, 2009. 